\title{
Dana Desa dan Status Desa di Provinsi Jawa Tengah
}

\author{
Village Funds and Village Status in Central Java Province \\ Yulitasari $^{1 *}$ \& Wido Prananing Tyas ${ }^{1}$ \\ ${ }^{1}$ Departemen Perencanaan Wilayah dan Kota, Fakultas Teknik, Universitas Diponegoro, \\ Jalan Prof. Sudharto, SH Tembalang, Semarang, Jawa Tengah 50275, Indonesia; \\ *Penulis korespondensi.e-mail: yulitasari.siswanto@gmail.com \\ (Diterima: 29 Maret 2020; Disetujui: 22 Mei 2020)
}

\begin{abstract}
Year 2019 is the fifth year of implementation of village fund in Indonesia. At the beginning of its implementation in 2015, village funds were budgeted at IDR 20.8 trillion, which has increased to 3.5 times and reaching about IDR 70 trillion in 2019. This research is aimed to describe village funds and villages status in Central Java Province and the relationship between them. Data to be used are secondary data consisting of village funds and village status according to IDM year 2018 and 2019 in Central Java Province. The analyses used in this research are descriptive statistics and simple regression. Results show that village funds in Central Java Province increase about 14.7\% in 2019 and there is an increase in the aggregate of village status. Regression analysis showed that changes in the amount of village funds did not significantly affect the change of village status in Central Java Province.
\end{abstract}

Keywords: Central Java Province, IDM, simple regression, village funds, village status

\begin{abstract}
ABSTRAK
Pemanfaatan dana desa pada tahun 2019 telah memasuki tahun ke-5. Dana desa yang dianggarkan pada tahun 2015 hanya sebesar Rp 20.8 Triliun dan telah meningkat hingga 3.5 kali lipatnya menjadi Rp 70 Triliun di tahun 2019. Penelitian ini bertujuan untuk menggambarkan tentang dana desa dan status desa di Provinsi Jawa Tengah, serta kaitan antara keduanya. Penelitian ini menggunakan data sekunder berupa data besaran dana desa dan status desa menurut Indeks Desa Membangun (IDM) tahun 2018 dan 2019 di Provinsi Jawa Tengah. Penelitian ini menggunakan analisis berupa statistik deskriptif dan regresi sederhana. Hasil penelitian menunjukkan bahwa dana desa di Provinsi Jawa Tengah mengalami kenaikan sebesar $14.7 \%$ di tahun 2019 dan terjadi kenaikan agregat terhadap status desa. Analisis regresi menunjukkan bahwa perubahan besaran dana desa tidak berpengaruh secara signifikan terhadap perubahan status desa di Provinsi Jawa Tengah.
\end{abstract}

Kata kunci: dana desa, Indeks Desa Membangun, Provinsi Jawa Tengah; regresi sederhana, status desa

\section{PENDAHULUAN}

Kesenjangan antara perkotaan dan perdesaan selalu menjadi isu yang hangat diperbincangakan dan coba diatasi oleh pemerintah. Berbagai cara ditempuh dan berbagai program dicanangkan untuk mengembangkan dan memajukan desa dalam rangka mengurangi kesenjangan yang terjadi. Keberhasilan dari program-program tersebut 
terkadang sulit untuk diukur salah satunya dikarenakan belum adanya instrumen pengukuran yang memadai. Indeks Desa Membangun atau disingkat IDM merupakan salah satu instrumen pengukuran tingkat pembangunan desa. Adanya IDM ini, diharapkan dapat menggambarkan bagaimana kondisi desa-desa di Indonesia dan bagaimana capaian program pembangunannya.

Program pembangunan desa dilakukan dalam mengembangkan desa sesuai dengan kearifan lokal yang didasarkan dengan nilainilai ekonomi, sosial maupun budaya. Widjaja (2010) menyebutkan bahwa pembangunan di perdesaan harus terus dilakukan atau ditingkatkan untuk mengangkat tingkat ekonomi masyarakat perdesaan dan menyejahterakannya.

Kebijakan adanya dana desa oleh pemerintah diharapkan mampu mendorong ekonomi masyarakat perdesaan, sehingga ke depannya desa-desa yang ada menjadi desadesa yang mandiri. Pada saat pertama kali diluncurkan, jumlah dana desa yang dianggarkan di tahun 2015 berjumlah Rp 20.67 Triliun. Jumlah dana ini setiap tahunnya mengalami peningkatan. Adapun untuk tahun 2019 telah menjadi sebesar Rp 70 Triliun. (Kementerian Desa, Pembangunan Daerah Tertinggal dan Transmigrasi, 2019). Nilai dana desa yang diperoleh masing-masing desa dipengaruhi oleh jumlah penduduk, luas desa, tingkat kemiskinan desa dan kesulitan geografis desa.

Sejauh mana desa telah berkembang dapat dilihat dari nilai IDM-nya. Melalui IDM status kemajuan dan kemandirian dana desa dapat ditentukan. Terdapat lima tingkatan status desa menurut nilai IDM-nya yaitu: desa mandiri, desa maju, desa berkembang, desa tertinggal, serta desa sangat tertinggal. IDM merupakan nilai komposit dari beberapa indeks ketahanan sebagaimana dapat terlihat secara lengkap dalam Gambar 1.

Pada tahun 2015, status desa di Indonesia didominasi oleh desa tertinggal dan pemerintah menargetkan dalam 5 tahun akan mengeluarkan 5,000 desa dari status tertinggal (dan sangat tertinggal) dan mewujudkan setidaknya 2,000 desa mandiri (Kementerian Desa, Pembangunan Daerah Tertinggal dan Transmigrasi, 2015).

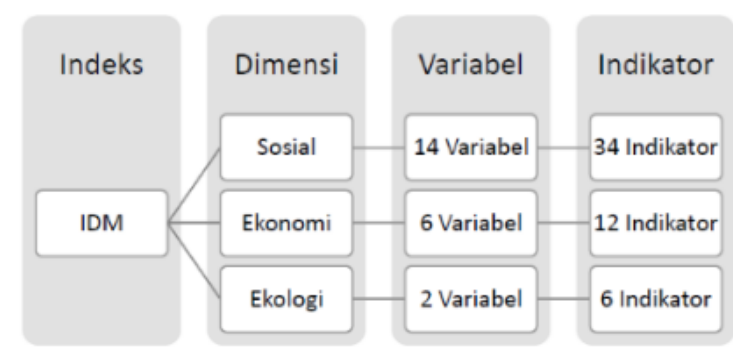

Gambar 1. Dimensi, variabel dan indikator pengukuran Indeks Desa Membangun (IDM) Sumber: Keputusan Menteri Desa, Pembangunan Daerah Tertinggal dan Transmigrasi Nomor 2 Tahun 2016, diolah

Provinsi Jawa Tengah menempati urutan ketiga sebagai provinsi dengan penduduk terbanyak di Indonesia. Pada tahun 2010, jumlah penduduk Provinsi Jawa Tengah tercatat sebanyak 32.4 juta jiwa dan dengan laju pertumbuhan penduduk sebesar 0.79 diprediksi pada tahun 2035 penduduk Provinsi Jawa Tengah akan mencapai angka 37.2 juta jiwa (BPS). Pada tahun 2010, sebanyak $45.7 \%$ atau sekitar 14.8 juta jiwa penduduk Provinsi Jawa Tengah bermukim di daerah perkotaan dan sisanya sebanyak $54.3 \%$ atau 17.6 juta jiwa bermukim di kawasan perdesaan. Menurut proyeksi BPS, penduduk perkotaan di Provinsi Jawa Tengah akan meningkat hingga $60.8 \%$ di tahun 2035. Persentase ini merupakan yang terendah di antara Provinsi-Provinsi di Pulau Jawa. Penduduk kawasan perdesaan Provinsi Jawa Tengah sejumlah 17.6 juta jiwa menghuni sebanyak 7,809 desa. Dengan jumlah desa sebanyak itu menjadikan Provinsi Jawa Tengah mempunyai jumlah desa terbanyak di Indonesia. Provinsi Jawa Tengah pada tahun 2009 menerima dana desa sebesar Rp 7.8 Triliun atau kurang lebih $10 \%$ dari total dana desa di Indonesia, menjadikannya sebagai provinsi dengan dana desa terbesar di Indonesia.

Jika melihat dari status desanya, desadesa di Provinsi Jawa Tengah pada tahun 2015 dapat dikelompokkan menjadi 21 desa mandiri, 868 desa maju, 4,335 desa berkembang, 2,535 
desa tertinggal, serta 50 desa sangat tertinggal, (Surat Keputusan Direktur Jenderal Pembangunan dan Pemberdayaan Masyarakat Desa Nomor 30 Tahun 2016). Adapun tahun 2019, desa-desa di Provinsi Jawa Tengah mengalami banyak perbaikan dan peningkatan. Pada tahun 2019, di antara 7,809 desanya telah terwujud 117 desa mandiri dan hanya menyisahkan 15 desa $(0.2 \%)$ yang berstatus sangat tertinggal dan 603 desa (7.7\%) tertinggal (Surat Keputusan Direktur Jenderal Pembangunan dan Pemberdayaan Masyarakat Desa Nomor 201 Tahun 2019).

Berbagai penelitian telah dilaksanakan untuk melihat pengaruh dana desa terhadap pembangunan desa. Dalam penelitiannya, Jamaluddin et al. (2018) menyimpulkan bahwa pertumbuhan pembangunan daerah tidak dipengaruhi oleh bagaimana dana desa dikelola dan dipergunakan. Serta kebijakan pembangunan Daerah yang tertuang dalam RPJMD belum dijadikan pedoman dalam penyusunan program pembangunan desa. Susilowati (2018), Sari \& Abdullah (2017), Muhtarom et al. (2018), Raharjo et al. (2018) dan Lalira et al. (2018) menemukan bahwa sarana dan prasarana fisik perdesaan masih menjadi fokus pemanfaatan dana desa tetapi dengan kualitas yang masih minim sehingga tujuan dana desa untuk peningkatan kesejahteraan masyarakat tidak berjalan efektif. Salah satu kemungkinan kenapa dana desa tidak berdampak signifikan terhadap pembangunan desa adalah karena belum optimalnya penatausahaan dana desa seperti yang ditemukan oleh Parasara (2017) di Desa Nglanggeran dan Desa Wareng di Kabupaten Gunung Kidul, Provinsi Daerah Istimewa Yogyakarta.

Pada penelitian yang lain disimpulkan bahwa dana desa memiliki peranan dalam meningkatkan kesejahteraan penduduk dengan memberikan lapangan pekerjaan dan perbaikan infrastruktur dasar sesuai dengan pendapat dari Atmojo et al. (2017), Tangkumahat et al. (2017), Sofianto (2017), Qhamariyah \& Zuhriyati (2019) dan Karmawan et al. (2020),
Gan et al. (2020), serta Azwardi \& Sukanto (2014).

Kunci yang menjadikan kesuksesan pengelolaan dana desa adalah adanya pelibatan masyarakat dalam setiap tahapan pelaksanaan, peningkatan kapasitas pengelola, serta monitoring dan evaluasi yang ketat sebagaimana dikemukakan oleh Daraba (2017), Aziz (2016), Putra et al. (2013), serta Arifa, (2019).

Penelitian ini mencoba mengambarkan tentang bagaimana sebaran desa berdasarkan dana desa dan status desa di Provinsi Jawa Tengah dan bagaimana kaitan antara keduanya. Hasil penelitian ini diharapkan sebagai referensi pada Ilmu Perencanaan Wilayah dan Kota, khususnya permasalahan dan perencanaan pembangunan salah satunya social capital mobilisation in policy making. Selain itu, menjadi referensi masyarakat agar dapat turut serta melakukan pengawasan terkait dengan dana desa serta peningkatan status desa pada indeks desa membangun di Provinsi Jawa Tengah. Di samping itu, dapat dijadikan pertimbangan dan rujukan dalam penyusunan kebijakan dana desa bagi pemerintah.

\section{METODOLOGI}

Pendekatan penelitian yang digunakan dengan metode kuantitatif. Metode ini dipilih dikarenakan data yang digunakan berupa data angka yang terukur dan dapat saling diperbandingkan (Sugiyono, 2013). Analisa yang digunakan adalah analisa statistika deskriptif dan analisa regresi sederhana. Statistika deskriptif digunakan untuk melihat bagaimana desa-desa di Provinsi Jawa Tengah tersebar menurut status desa pada tahun 2018 dan tahun 2019, perubahan status desa yang dialami, serta perubahan besaran dana desa yang dianggarkan. Untuk melihat bagaimana keterkaitan antara status desa dengan dana desa digunakan analisa regresi sederhana.

Data yang dipakai yaitu data sekunder berupa data dana desa dan nilai IDM per desa di Provinsi Jawa Tengah Tahun 2018 dan Tahun 2019. Data yang digunakan berasal dari sumber 
data terpercaya yaitu Kementerian Desa, Pembangunan Daerah Tertinggal dan Transmigrasi, khususnya Pusat Data dan Informasi untuk data besaran dana desa serta Sekretariat Direktorat Jenderal Pembangunan dan Pemberdayaan Masyarakat Desa untuk data IDM.

Analisis regresi sederhana digunakan utuk memodelkan hubungan antara peubah bebas dan peubah terikat yang masing-masing berjumlah satu dimana hubungan di antara keduanya harus bersifat linear. (Sugiyono, 2013). Model analisis regresi sederhana dapat digunakan (1) untuk menduga atau memperkirakan nilai peubah terikat berdasarkan nilai peubah bebas dan (2) mengukur pengaruh peubah bebas terhadap peubah terikat berdasarkan hubungan sebab akibat. Model regresi linier sederhana secara matematis diuraikan berikut ini:

dengan:

$$
\mathrm{Y}=\mathrm{A}+\mathrm{BX}+\mathrm{e}
$$

Y sebagai variabel dependen atau respon

$\mathrm{X}$ sebagai variable independen (variable bebas)

A sebagai konstanta/ intercept

B sebagai slope/ koefisien regresi

e sebagai error/ residual

Variabel dalam penelitian ini yaitu variabel bebas (independent) $(\mathrm{X})=$ perubahan besaran dana desa = dana desa tahun 2019 dikurangi dana desa tahun 2018 (dalam miliar rupiah) dan variabel terikat (dependent) $(\mathrm{Y})=$ perubahan nilai IDM = nilai IDM tahun 2019 dikurangi nilai IDM tahun 2018.

Hipotesis pada penelitian ini adalah perubahan dana desa signifikan berpengaruh pada perubahan status desa.

\section{HASIL DAN PEMBAHASAN}

\section{Dana Desa Tahun 2018 dan 2019 di Provinsi Jawa Tengah}

Dana desa di Provinsi Jawa Tengah tahun 2018 disalurkan untuk 7,809 desa dengan total dana desa dianggarkan sejumlah $\mathrm{Rp}$ $6,735,002,226,000.00$ (enam triliun tujuh ratus tiga puluh lima miliar dua juta dua ratus dua puluh enam ribu rupiah) dengan besaran dana desa berkisaran antara $\mathrm{Rp} 637,400,000.00$ (enam ratus tiga puluh tujuh juta empat ratus ribu rupiah) di Desa Wingkomulyo, Kecamatan Ngombol, Kabupaten Purworejo hingga Rp 2,428,981,000.00 (dua miliar empat ratus dua puluh delapan juta sembilan ratus delapan puluh satu ribu rupiah) di Desa Pamulihan, Kecamatan Larangan, Kabupaten Brebes dengan rata-rata per desa mendapat dana desa sebesar Rp 862,466,670.00 (Delapan ratus enam puluh dua juta empat ratus enam puluh enam ribu enam ratus tujuh puluh rupiah). Jika dilihat dari total satu Kabupaten, Dana Desa terbesar terdapat di Kabupaten Pati dengan total Rp 365,454,541,000.00 (tiga ratus enam puluh lima miliar empat ratus lima puluh empat juta lima ratus empat puluh satu ribu rupiah) dan terkecil terdapat di Kabupaten Kudus dengan total dana desa yang dianggarkan sebesar Rp 117,966,044,000.00 (Seratus tujuh belas miliar sembilan enam puluh enam juta empat puluh empat ribu rupiah). Jika dilihat dari rata-rata per desa maka Kabupaten dengan rata-rata dana desa terbesar terdapat di Kabupaten Pemalang dengan Rp 1,181,623,488.00 (satu miliar seratus delapan puluh satu juta enam ratus dua puluh tiga ribu empat ratus delapan puluh delapan rupiah) dan rata-rata dana desa terkecil terdapat di Kabupaten Purworejo Rp 695,277,578.00 (enam ratus sembilan puluh lima juta dua ratus tujuh puluh tujuh ribu lima ratus tujuh puluh delapan rupiah).

Pada tahun 2019, jumlah desa yang mendapatkan dana desa masih sejumlah 7,809 desa tetapi terjadi peningkatan dari dari segi total dana yang dianggarkan sebesar Rp 1,154,426,370,000.00 (satu triliun seratus lima puluh empat miliar empat ratus dua puluh enam juta tiga ratus tujuh puluh ribu rupiah) menjadi sebesar Rp 7,889,428,596,000.00 (tujuh triliun delapan ratus delapan puluh sembilan miliar empat ratus dua puluh delapan juta lima ratus sembilan enam ribu rupiah) atau naik sebesar $17.4 \%$. Sehingga setiap desa rata-rata menerima dana desa sebesar Rp 1,010,299,474.00 (satu miliar sepuluh juta dua ratus sembilan puluh 
sembilan ribu empat ratus tujuh puluh empat rupiah). Dana desa terbesar dianggarkan untuk desa Pamulihan, Kecamatan Larangan, Kabupaten Brebes sebesar Rp 3,597,033,000.00 (tiga miliar lima ratus sembilan puluh tujuh juta tiga puluh tiga ribu rupiah) dan yang terkecil dianggarkan untuk Desa Wingkoharjo, Kecamatan Ngombol, Kabupaten Purworejo sebesar Rp 699,678,000.00 (enam ratus sembilan puluh sembilan juta enam ratus tujuh puluh delapan ribu rupiah). Dilihat dari total satu Kabupaten, dana desa terbesar terdapat di Kabupaten Brebes dengan total $\mathrm{Rp}$ 441,009,459,000.00 (Empat ratus empat puluh satu miliar sembilan juta empat ratus lima puluh sembilan ribu rupiah) dan terkecil terdapat di Kabupaten Kudus dengan total dana desa yang dianggarkan sebesar Rp 139,077,753,000.00 (seratus tiga puluh sembilan miliar tujuh puluh tujuh juta tujuh ratus lima puluh tiga ribu rupiah). Sedangkan, jika dilihat dari rata-rata per desa maka Kabupaten dengan rata-rata dana desa terbesar terdapat di Kabupaten Brebes dengan Rp 1,510,306,366.00 (satu miliar lima ratus sepuluh juta tiga ratus enam ribu tiga ratus enam puluh enam rupiah) dan rata-rata dana desa terkecil terdapat di Kabupaten Purworejo Rp 786,911,957.00 (tujuh ratus delapan puluh enam juta sembilan ratus sebelas ribu sembilan ratus lima puluh tujuh rupiah).

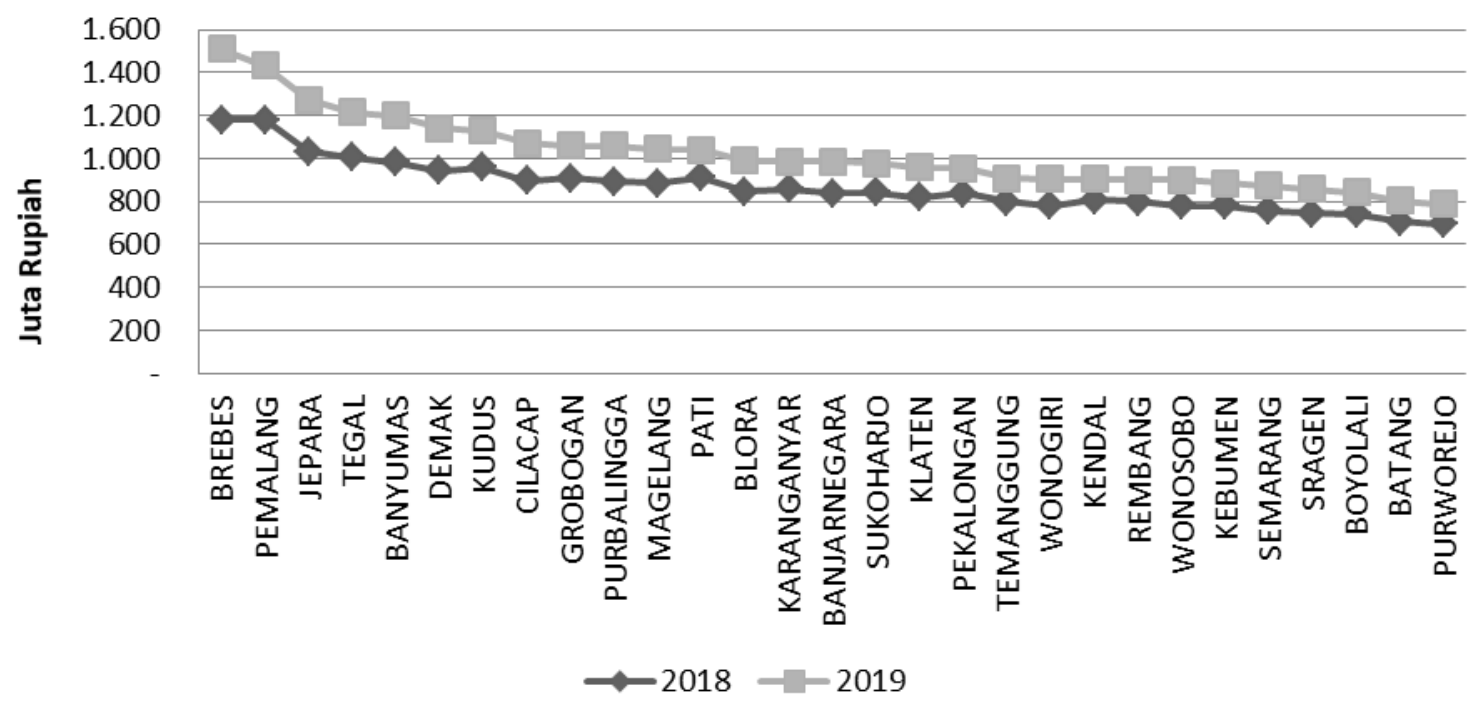

Gambar 2. Rata-rata dana desa yang diterima per desa menurut Kabupaten di Provinsi Jawa Tengah

Walaupun secara garis besar, jumlah dana desa meningkat dari tahun 2018 ke tahun 2019, tetapi terdapat 496 desa yang mengalami penurunan besaran dana desa. Desa Lebak, Kecamatan Pakis Aji, Kabupaten Jepara merupakan desa yang mengalami kenaikan dana desa terbesar yaitu sebesar $\mathrm{Rp}$ 1,542,818,000.00 (satu miliar lima ratus empat puluh dua juta delapan ratus delapan belas ribu rupiah) (132.89\%) dari semula $\mathrm{Rp}$ $1,160,964,000.00$ (satu miliar seratus enam puluh juta sembilan ratus enam puluh empat ribu rupiah) pada tahun 2018 menjadi $\mathrm{Rp}$ 2,703,782,000.00 (dua miliar tujuh ratus tiga juta tujuh ratus delapan puluh dua ribu rupiah) pada tahun 2019. Sedangkan desa yang mengalami penurunan dana desa terbesar dialami oleh Desa Sumberagung, Kecamatan Klego, Kabupaten Boyolali. Desa Sumberagung mengalami penurunan dana desa sebesar $\mathrm{Rp}$ 464,254,000.00 (empat ratus enam puluh empat juta dua ratus lima puluh empat ribu rupiah) (33.77\%) dari semula $\operatorname{Rp~1,374,741,000.00~}$ (satu miliar tiga ratus tujuh puluh empat juta tujuh ratus empat puluh satu ribu rupiah) pada tahun 2018 menjadi Rp 910,487,000.00 (sembilan ratus sepuluh juta empat ratus delapan puluh tujuh ribu rupiah) pada tahun 2019. Jika dilihat per Kabupaten, maka semua Kabupaten mengalami peningkatan jumlah dana 
desa dan yang mengalami peningkatan terbesar adalah Kabupaten Brebes dengan jumlah peningkatan sebesar $\operatorname{Rp} 96,811,963,000.00$ (sembilan puluh delapan miliar delapan ratus sebelas juta sembilan ratus enam puluh tiga ribu rupiah) $(28.12 \%)$.

Di Kabupaten Brebes, semua desa mengalami kenaikan dana desa dan tidak ada desa yang mengalami penurunan dana desa. Kabupaten dengan jumlah desa terbanyak yang mengalami penurunan dana desa adalah di Kabupaten Kebumen yaitu sebanyak 44 desa. Sedangkan jika dilihat dari persentase, Kabupaten dengan persentase terbesar desa yang mengalami penurunan ada di Kabupaten Pekalongan dengan 41 desa dari total 272 desa atau $15.07 \%$ mengalami penurunan dana desa.

\section{Status Desa Tahun 2018 Dan 2019 di Provinsi Jawa Tengah}

Pada Tabel 1 terlihat status desa terbanyak baik pada tahun 2018 maupun 2019 adalah desa berkembang (65.44\% dan $71.46 \%$ ). Pada tahun 2018, status desa terbanyak kedua adalah desa dengan status tertinggal yaitu sebanyak 1,366 desa atau sebanyak $17.49 \%$. Keadaan menunjukan bahwa terdapat perbaikan dengan banyaknya peningkatan status desa, dimana status desa terbanyak kedua di tahun 2019 tidak lagi desa tertinggal tetapi adalah desa maju yaitu sebanyak 1,494 desa atau sebanyak $19.13 \%$ dan berkurangnya jumlah desa sangat tertinggal. Pada tahun 2018 terdapat sebanyak 52 desa tertinggal tetapi pada tahun 2019 hanya tersisa sebanyak 15 desa tertinggal.

Tabel 1. Jumlah desa berdasarkan status desa di Provinsi Jawa Tengah

\begin{tabular}{lrrrr}
\hline Status desa & \multicolumn{2}{l}{ Tahun 2018 } & \multicolumn{3}{l}{ Tahun 2019 } \\
& $\begin{array}{l}\text { Jumlah } \\
\text { desa }\end{array}$ & $\%$ & $\begin{array}{l}\text { Jumlah } \\
\text { desa }\end{array}$ & $\%$ \\
\hline Mandiri & 69 & 0.88 & 117 & 1.50 \\
\hline Maju & 1,032 & 13.22 & 1,494 & $\begin{array}{r}19.1 \\
3\end{array}$ \\
\hline Berkembang & 5,110 & 65.44 & 5,580 & $\begin{array}{r}71.4 \\
6\end{array}$ \\
\hline Tertinggal & 1,366 & 17.49 & 603 & 7.72 \\
\hline $\begin{array}{l}\text { Sangat } \\
\text { Tertinggal }\end{array}$ & 52 & 0.67 & 15 & 0.19 \\
\hline $\begin{array}{l}\text { Tidak } \\
\text { Tersedia }\end{array}$ & 180 & 2.31 & & - \\
Data & & & & \\
\hline
\end{tabular}

Dibandingkan tahun 2018, pada tahun 2019 terdapat 1,636 desa yang mengalami peningkatan status desa, 345 desa mengalami penurunan status desa dan 5,648 desa tidak mengalami perubahan status desa serta 180 desa tidak dapat dinilai apakah mengalami perubahan atau tidak dikarenakan data status desa pada tahun 2018 tidak tersedia. Ke-180 desa tersebut bukan merupakan desa hasil pemekaran tetapi data IDM pada tahun 2018 tidak dapat dihitung karena satu dan lain hal. Kabupaten dengan peningkatan status desa terbanyak adalah Kabupaten Purworejo, dimana terdapat 248 desa yang mengalami kenaikan status dan hanya 1 desa yang mengalami penurunan status. Data lebih lengkap ditunjukkan pada Tabel 2 dan Gambar 3.

Tabel 2. Perubahan status desa tahun 2019 di Provinsi Jawa Tengah

\begin{tabular}{|c|c|c|c|c|c|c|}
\hline \multirow[b]{2}{*}{ Status desa 2018} & \multicolumn{6}{|c|}{ Status desa 2019} \\
\hline & Mandiri & Maju & Berkembang & Tertinggal & $\begin{array}{c}\text { Sangat } \\
\text { tertinggal }\end{array}$ & Total \\
\hline Mandiri & 52 & 15 & 2 & 0 & 0 & 69 \\
\hline Maju & 42 & 803 & 183 & 4 & 0 & 1,032 \\
\hline Berkembang & 18 & 599 & 4,354 & 138 & 1 & 5,110 \\
\hline Tertinggal & 1 & 67 & 869 & 427 & 2 & 1,366 \\
\hline Sangat tertinggal & 1 & 2 & 24 & 13 & 12 & 52 \\
\hline Data tidak tersedia & 3 & 8 & 148 & 21 & 0 & 180 \\
\hline Total & 117 & 1,494 & 5,580 & 603 & 15 & 7,809 \\
\hline
\end{tabular}




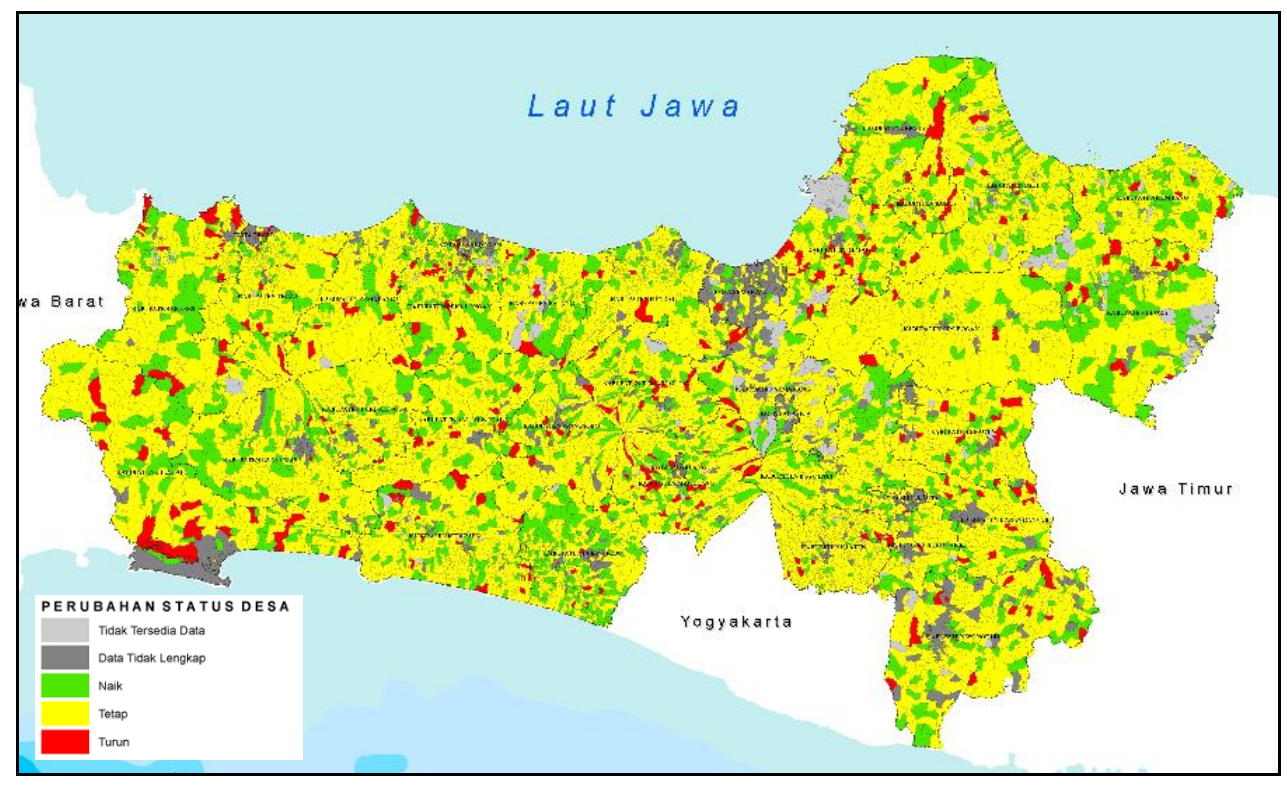

Gambar 3. Sebaran desa yang mengalami perubahan status desa menurut Indeks Desa Membangun tahun 2018 dan 2019 di Provinsi Jawa Tengah

Jika dilihat lebih rinci terdapat beberapa desa yang mengalami kenaikan atau penurunan lebih dari satu tingkatan. Desa-desa yang mengalami kenaikan status lebih dari satu tingkatan antara lain Desa Prawatan di Kecamatan Jogonalan, Kabupaten Klaten; Desa Mojowetan di Kecamatan Bajarejo dan Desa Sonokidul di Kecamatan Kunduran Kabupaten Blora; serta Desa Kelurahan di Kecamatan Jambu, Kabupaten Semarang. Desa-desa yang mengalami penurunan lebih dari dua tingkatan antara lain adalah Desa Bakung di Kecamatan Jogonalan, Kabupaten Klaten; Desa Jepangpakis di Kecamatan Jati, Kabupaten Kudus; Desa Sidokumpul di Kecamatan Guntur, Kabupaten Demak; Desa Sumingkir di Kecamatan Kutasari, Kabupaten Purbalingga; Desa Tenggak di Kecamatan Sidoharjo, Kabupaten Sragen; Desa Batursari di Kecamatan Kledung, Kabupaten Temanggung serta Tritih Lor di Kecamatan Jeruklegi, Kabupaten Cilacap.

Tabel 3. Sandingan perubahan dana desa dengan perubahan status desa di Provinsi Jawa Tengah

\begin{tabular}{|c|c|c|c|c|c|c|}
\hline \multirow[b]{2}{*}{ Dana desa } & & \multicolumn{5}{|c|}{ Status desa } \\
\hline & & $\begin{array}{c}\text { Data Lengkap Tidak } \\
\text { Tersedia }\end{array}$ & Naik & Tetap & Turun & Total \\
\hline \multirow[t]{2}{*}{ Naik } & JLH & 180 & 1,607 & 5,207 & 319 & 7,313 \\
\hline & $\%$ & $2.46 \%$ & $21.97 \%$ & $71.20 \%$ & $4.36 \%$ & $93.65 \%$ \\
\hline \multirow[t]{2}{*}{ Turun } & JLH & & 29 & 441 & 26 & 496 \\
\hline & $\%$ & $0.00 \%$ & $5.85 \%$ & $88.91 \%$ & $5.24 \%$ & $6.35 \%$ \\
\hline \multirow[t]{2}{*}{ Grand total } & JLH & 180 & 1,636 & 5,648 & 345 & 7,809 \\
\hline & $\%$ & $2.31 \%$ & $20.95 \%$ & $72.33 \%$ & $4.42 \%$ & $100 \%$ \\
\hline
\end{tabular}

\section{Identifikasi Keterkaitan Status Desa dan Dana Desa di Provinsi Jawa Tengah}

Pada tahun 2019, dari total 7,313 desa mengalami kenaikan dana desa, 1,607 desa di antaranya mengalami kenaikan status desa (21.97\%), 319 desa mengalami penurunan status $(4.36 \%)$ dan 5,207 tetap pada status sebelumnya (tidak mengalami perubahan status) $(71.20 \%)$ serta 180 desa yang status desa pada tahun 2018 tidak diketahui tidak dapat dinilai. Sedangkan dari 496 desa yang mengalami penurunan dana desa, terdapat 29 desa mengalami kenaikan status desa (5.85\%), 26 desa mengalami penurunan status desa $(5.24 \%)$ dan sisanya sebanyak 441 desa tidak mengalami perubahan status (88.91\%). 
Tabel 4. Sandingan status desa tahun 2018 dengan perubahan besaran dana desa tahun 2019

\begin{tabular}{lrrr}
\hline \multicolumn{1}{c}{$\begin{array}{c}\text { Status } \\
\text { desa tahun } \\
2018\end{array}$} & \multicolumn{3}{c}{$\begin{array}{c}\text { Besaran dana desa } \\
\text { tahun 2019 }\end{array}$} \\
\cline { 2 - 4 } & Naik & \multicolumn{1}{c}{ Turun } & \multicolumn{1}{c}{ Total } \\
\hline Mandiri & 67 & 2 & 69 \\
\hline Maju & 1,001 & 31 & 1,032 \\
\hline $\begin{array}{l}\text { Berkemba } \\
\text { ng }\end{array}$ & 4,657 & 453 & 5,110 \\
\hline Tertinggal & 1,356 & 10 & 1,366 \\
\hline $\begin{array}{l}\text { Sangat } \\
\text { tertinggal }\end{array}$ & 52 & 0 & 52 \\
\hline $\begin{array}{l}\text { Data tidak } \\
\text { lengkap }\end{array}$ & 180 & 0 & 180 \\
\hline $\begin{array}{c}\text { Grand } \\
\text { Total }\end{array}$ & 7,313 & 496 & 7,809 \\
\hline
\end{tabular}

Jika didasarkan pada status desa tahun 2018, sebanyak 52 desa berstatus desa sangat tertinggal mengalami kenaikan dana desa dengan besaran yang beragam berkisar antara Rp 10,045,000.00 (sepuluh juta empat puluh lima ribu rupiah) di Desa Purworejo, Kecamatan Bonang, Kabupaten Demak hingga sebesar Rp 797,815,000.00 (tujuh ratus sembilan puluh tujuh juta delapan ratus lima belas ribu rupiah) di Desa Wonosekar, Kecamatan Karangawen, Kabupaten Demak. Sedangkan untuk 1,356 desa berstatus desa tertinggal, 10 desa di antaranya mengalami penurunan dana desa, dengan penurunan terbesar dialami oleh Desa Harjobinanggun, Kecamatan Grabag, Kabupaten Purworejo sebesar Rp 83,006,000.00 (delapan puluh tiga juta enam ribu rupiah) dan penurunan terkecil dialami oleh Desa Candimulyo, Kecamatan Sedan, Kabupaten Rembang sebesar Rp 181,000.00 (seratus delapan puluh satu ribu rupiah).

\section{Relasi Dana Desa dengan Status Desa}

Persamaan regresi yang didapatkan adalah $\mathrm{Y}=0.015127+0.057849 \mathrm{X}$ dengan nilai korelasi sebesar 0.115527278 , nilai KP sebesar $1.33 \%$ dan significant $\mathrm{F}$ sebesar $1.20533 \mathrm{E}^{-21}$. Dari hasil analisis dapat diartikan sebagai berikut:

a. Korelasi sebesar $=0.115527278$ berarti bahwa dana desa dan nilai IDM memiliki hubungan yang sangat lemah b. Nilai KP sebesar $1.33 \%$ berarti bahwa pengaruh variabel dana desa kepada variabel nilai IDM hanya sebesar $1.33 \%$ sedangkan 98.67\% sisanya ditentukan oleh variabel lainnya.

c. Significant F sebesar $1.20533 \mathrm{E}^{-21}<\alpha=5 \%$ artinya menolak $\mathrm{H} 0$ dan menerima $\mathrm{H} 1$ yaitu Perubahan besaran dana desa tidak berpengaruh secara signifikan terhadap perubahan status desa

d. Nilai IDM akan mengalami kenaikan sebesar 0.0515127 jika nilai $\mathrm{X}=0$ atau tidak terjadi perubahan besaran dana desa.

e. Nilai IDM akan bergerak sebesar 0.0057849 jika terjadi peningkatan 1 satuan $\mathrm{X}$ yaitu terjadi peningkatan dana desa sebesar $\mathrm{Rp}$ $1,000,000,000.00$.

Hasil diatas diketahui jika dana desa mempengaruhi status desa secara positif, tetapi pengaruhnya tersebut tidak signifikan. Faktorfaktor lain di luar dana desa lebih berpengaruh dalam perubahan status desa.

\section{KESIMPULAN DAN REKOMENDASI}

Sebaran dana desa di Provinsi Jawa Tengah tidak mengalami perubahan yang berarti antara tahun 2018 dan tahun 2019 dimana jumlah desa di Provinsi Jawa Tengah ada sebanyak 7,809 desa dengan jumlah dana desa yang dianggarkan pada tahun 2018 sebesar Rp 6,735,002,226,000.00 (enam triliun tujuh ratus tiga puluh lima miliar dua juta dua ratus dua puluh enam ribu rupiah) dan pada tahun 2019 sebesar Rp 7,889,428,596,000.00 (tujuh triliun delapan ratus delapan puluh sembilan miliar empat ratus dua puluh delapan juta lima ratus sembilan puluh enam ribu rupiah). Walaupun secara agregat terjadi peningkatan terhadap total dana desa yang dianggarkan yaitu sebesar Rp1,154,426,370,000.00 (satu triliun seratus lima puluh empat miliar empat ratus dua puluh enam juta tiga ratus tujuh puluh ribu rupiah) (17.4\%), tetapi terdapat 496 desa yang mengalami penurunan dana desa tahun $2019 \mathrm{di}$ Provinsi Jawa Tengah.

Dibandingkan tahun 2018, pada tahun 2019 terdapat sebanyak 1,636 desa mengalami 
peningkatan status desa, 345 desa mengalami penurunan status desa dan 5,648 desa tidak mengalami perubahan status serta terdapat 180 desa yang tidak dinilai karena data tidak lengkap. Pada tahun 2019 di Provinsi Jawa Tengah hanya tersisa 15 desa sangat tertinggal $(0.29 \%)$, tersisa 603 desa tertinggal $(7.72 \%)$, terdapat 5,580 desa berkembang (71.46\%), terdapat 1,494 desa maju (19.13\%) dan ada 117 desa dengan status mandiri (1.5\%).

Hasil analisis dengan regresi sederhana memperlihatkan bahwa di Provinsi Jawa Tengah, perubahan besaran dana desa tidak mempunyai pengaruh secara signifikan atas perubahan status desa. Sehubungan hal itu, terhadap dana desa yang semakin meningkat jumlahnya setiap tahunnya perlu dilakukan evaluasi terhadap dampaknya kepada perkembangan dan pembangunan desa. Peningkatan dana desa setiap tahunnya perlu disertai dengan monitoring dan evaluasi serta pembinaan yang intensif. Pembinaan yang dapat dilakukan antara lain adalah peningkatan kualitas sumber daya manusia perdesaan, dan peningkatan keterlibatan masyarakat dalam pengelolaan dana desa dan pembangunan desa.

\section{Keterbatasan Penulisan}

Penelitian ini dilakukan dengan keterbatasan dan kekurangan antara lain berupa:

1. Terdapat beberapa perbedaan antara data yang didapat penulis dari sumber data dengan data yang sudah beredar.

2. Tenggat waktu pengaruh dana desa terhadap IDM belum menjadi salah satu pertimbangan dalam analisis regresi.

Untuk itu perlu adanya pengkajian yang lebih seksama di masa mendatang dengan memperhitungkan keterbatasan di atas.

\section{REFERENSI}

Arifa, I. N. (2019). Community Participation and Government Role in Using Village Funds in Dlingo Village. Policy \& Governance Review, 3 (2), 171-185. http://doi.org/10.30589/pgr.v3i2.129
Atmojo, M. E., Fridayani, H. D., Kasiwi, A. N., \& Pratama, M. A. (2017). Efektivitas dana desa untuk pengembangan potensi ekonomi berbasis partisipasi masyarakat di Desa Bangunjiwo. Arista, 5 (1), 126-140.

Aziz, N. L. L. (2016). Otonomi Desa dan Efektivitas Dana Desa. Jurnal Penelitian Politik, 13 (2), 193-210.

Azwardi \& Sukanto. (2014). Efektifitas Alokasi Dana Desa (ADD) dan Kemiskinan di Provinsi Sumatera Selatan. Jurnal Ekonomi Pembangunan, 12 (1), 29-41.

BPS. (2013). Proyeksi Penduduk Indonesia 2010-2035. Badan Pusat Statistik.

Daraba, H. D. (2017). Pengaruh Program Dana Desa Terhadap Tingkat Partisipasi Masyarakat di Kecamatan Galesong Utara Kabupaten Takalar. Sosiohumaniora, 19 (1), 52-58.

Gani, A. O. A., Gani, A., \& Arief, M. (2020). Dampak Penggunaan Dana Desa Terhadap Indikator Ketahanan Sosial , Ekonomi dan Ekologi Desa Tertinggal Kecamatan Bulukumpa Kabupaten Bulukumba. Paradoks: Jurnal Ilmu Ekonomi, 3 (1), 78-88.

Jamaluddin, Y., Sumaryana, A., Rusli, B., \& Buchari, R. A. (2018). Analisis Dampak Pengelolaan dan Penggunaan Dana Desa terhadap Pembangunan Daerah. JPPUMA: Jurnal Ilmu Pemerintahan dan Sosial Politik UMA, 6 (1), 14-24.

Karmawan, Akbar, M. F., Yunita, A., Christianungrum, \& Yanuar, D. (2020). Contribution of Village Fund to Development and Social Empowerment and Coastal Community Economy in the Village of West Kurau and Village of Kurau in Central Bangka Regency. Journal of Talent Development and Excellence, Vol (12) No.3s, 1602-1610.

Kementerian Desa, Pembangunan Daerah Tertinggal dan Transmigrasi. (2019). www.sipede.kemendes.go.id 
Kementerian Desa, Pembangunan Daerah Tertinggal dan Transmigrasi. (2015). Indeks Desa Membangunan 2015. Jakarta

Lalira, D., Nakoko, A. T., \& Rorong, I. P. F. (2018). Pengaruh Dana Desa dan Alokasi Dana Desa Terhadap Tingkat Kemiskinan di Kecamatan Gemeh Kabupaten Kepulauan Talaud. Jurnal Berkala Ilmiah Efisiensi, 18 (04), 62 72.

Muhtarom, Kusuma, N., \& Purwanti, E. (2018). Analisis Indeks Desa Membangun untuk Mengetahui Pola Perkembangan Pembangunan Desa di Kecamatan Gadingrejo, Kabupaten Pringsewu. Journal Balitbangda Lampung, 6 (2), 179-190.

Parasara, A. A.P. (2017). Analisis Penatausahaan Dana Desa (Studi Pada Desa Nglanggeran dan Desa Wareng Kabupaten Gunungkidul). Tesis. Yogyakarta. Universitas Gadjah Mada

Putra, C. K., Pratiwi, R. N., \& Suwondo. (2013). Pengelolaan Alokasi Dana Desa dalam Pemberdayaan Masyarat Desa (Studi pada Desa Wonorejo Kecamatan Singosari Kabupaten Malang). Jurnal Administrasi Publik (JAP), 1 (6), 12031212.

Qhamariyah, S., \& Zuhriyati, E. (2019). Public Perception Of Optimization in The Village Fund Allocation Sub Distric Sayegan Sleman Year 2016. Proceeding ICOGISS 2019, 647-668.

Raharjo, T., Sulaeman, A. Su., \& Sriyani. (2018). Efektifitas Penggunaan Dana Desa. Bisman, 1 (2), 17-34.

Sari, I. M., \& Abdullah, M. F. (2017). Analisis Ekonomi Kebijakan Dana Desa Terhadap Kemiskinan Desa di Kabupaten Tulungagung. Junal Ekonomi Pembangunan, 15 (1), 34-49.

Sofianto, A. (2017). Kontribusi Dana Desa Terhadap Pembangunan dan Pemberdayaan Masyarakat di Kebumen dan Pekalongan. Matra Pembangunan, 1 (1), 23-32.
Sugiyono. (2013). Metode Penelitian Pendidikan Pendekatan Kuantitaif, Kualitatif, dan $R \& D$. Bandung: Alfabeta.

Susilowati, N. I. (2018). Pengaruh Alokasi Dana Desa, Dana Desa, Belanja Modal, dan Produk Domestik Regional Bruto terhadap Kemiskinan Kabupaten/Kota di Jawa Timur. Tugas akhir. Universitas Muhammadiyah Malang.

Tangkumahat, F. V., Panelewen, V. V. ., \& Mirah, A. D. (2017). Dampak Program Dana Desa Terhadap Peningkatan Pembangunan dan Ekonomi di Kecamatan Pineleng Kabupaten Minahasa. Agri-Sosio Ekonomi Unsrat, 13 (2A), 335-342.

Widjaja, H. A. W. (2010). Otonomi Desa merupakan Otonomi yang Asli, Bulat dan Utuh. Depok. RajaGrafindo Persada. 